\title{
Comparison of performance, digestibility of nutrients and quality of meat in four breeds of broiler rabbits
}

\author{
V Skrivanova 1, E Tumova 2, M Skrivan 2, M Marounek 3, \\ J Lastovkova ', M Kubouskova ${ }^{\dagger}$ \\ 'Research Institute of Animal Production, Prague $10 ;{ }^{2}$ Agricultural University Prague, Prague 6 ; \\ IInstitute of Animal Physiology and Genetics, Prague 10, Czech Republic
}

In the first experiment 56 weaned rabbits, 30 d old, were assigned to one of four groups (14 rabbits each) on basis of the genotype (Hyla, Zika, Hyplus, Cunistar). These breeds are common in Czech commercial rabbitries at present. Rabbits were kept in stainless steel mesh cages, 2 per cage, at $16^{\circ} \mathrm{C}$. In the second experiment 20 weaned rabbits of the same breeds were individually housed in metabolic cages in order to perform digestibility trials. Rabbits were fed a granulated feed mixture containing (\%): crude protein 14.8 , fat 3.5 , crude fibre 15.6 , ash 6.7. Rabbits were killed at $80 \mathrm{~d}$ of age and muscles from the leg removed for meat quality evaluation.

Differences among breeds tested were relatively small, although some of them were statistically significant. Rabbits of the Cunistar breed gained less than other rabbits and consumed more feed per $1 \mathrm{~kg}$ of gain. On the other hand the fibre digestibility in Cunistar rabbits was relatively high. In samples of meat of Cunistar rabbits both fat and cholesterol were elevated in comparison with other breeds. Fat and cholesterol content in rabbit meat was, however, generally low as compared with meat of other farm animals.

Results are summarized in the following table:

\begin{tabular}{|c|c|c|c|c|}
\hline & & & & \\
\hline & Hyla & Zika & Hyplus & Cunistar \\
\hline Performance 1 & & & -- & -- \\
\hline Avg. daily gain (g) & $38(41)$ & $37(39)$ & $40(40)$ & 35 (36) \\
\hline Feed conversion $(\mathrm{kg} / \mathrm{kg})$ & $3.1(3.4)$ & $3.2(3.6)$ & $2.9(3.6)$ & $3.4(4.0)$ \\
\hline Final weight $(\mathrm{g})$ & $2679(2961)$ & $2647(2847)$ & $2552(2890)$ & $2550(2772)$ \\
\hline Digestibility (\%) ${ }^{2}$ & & & & \\
\hline Crude protein & $64.1 / 51.4$ & $63.0 / 60.2$ & $66.1 / 64.2$ & $62.4 / 62.1$ \\
\hline Crude fibre & $24.0 / 13.5$ & $21.6 / 18.9$ & $20.3 / 21.0$ & $30.6 / 24.6$ \\
\hline Meat composition $(\mathrm{g} / \mathrm{kg})^{1}$ & & & & \\
\hline Dry matter & $273(269)$ & $255(266)$ & $264(277)$ & $272(283)$ \\
\hline Protein & $210(211)$ & $208(210)$ & $209(206)$ & $208(208)$ \\
\hline Fat & $45.9(430)$ & $31.8 \mathrm{a}(39.6)^{\mathrm{a}}$ & $39.2(50.9)$ & $47.7^{\mathrm{b}}(55.0)^{\mathrm{b}}$ \\
\hline Cholesterol & $0.67(0.60)$ & $0.61 \mathrm{a}(0.56)^{\mathrm{a}}$ & $0.68(0.69)$ & $0.73^{\mathrm{b}}(0.70)^{\mathrm{b}}$ \\
\hline Hydroxyproline & $1.59(1.30)$ & $1.35(1.50)$ & $1.48(1.80)$ & $1.58(1.70)$ \\
\hline
\end{tabular}

